УДК 615.07:615.32:543.544.943.3.068.7

DOI https://doi.org/10.11603/2312-0967.2021.2.12182

\title{
ВИЗНАЧЕННЯ КІЛЬКІСНОГО ВМІСТУ СУМИ ФЛАВОНОЇДІВ У НАСТОЙЦІ НАГІДОК МЕТОДОМ ВИСОКОЕФЕКТИВНОЇ ТОНКОШАРОВОЇ ХРОМАТОГРАФІЇ
}

\author{
К. О. Хохлова, Л. І. Вишневська, О. А. Здорик \\ Національний фрармацевтичний університет, Харків \\ Kateryna_khokhlova@ukr.net
}

ІНФОРМАЦІЯ

Надійшла до редакції / Received: 31.05.2021

Після доопрацювання / Revised: 03.06.2021

Прийнято до друку / Accepted: 05.06.2021

\section{Ключові слова:}

настойка нагідок;

високоефективна тонкошарова

хроматограсрія;

сума фрлавоноїдів;

рутин;

кількісне визначення.
АНОТАЦІЯ

Мета роботи. Розробка методики визначення кількісного вмісту суми фрлавоноїдів настойки нагідок методом високоефективної тонкошарової хроматограсрії (ВЕТШХ), що характеризується специсрічністю, експресністю та економічністю.

Матеріали і методи. Дослідження проведено методом ВЕТШХ в автоматичній системі виробництва CAMAG (Швейцарія) на базі Навчально-наукової тренінгової лабораторії хіміко-технологічних досліджень НФаУ (Харків, Україна). Результати обробляли за допомогою програмного забезпечення visionCats, CAMAG. Як стандартний зразок (С3) використовували рутин, як об'єкти дослідження - три зразки настойки нагідок вітчизняних виробників.

Результати й обговорення. При розробці методики обрано оптимальні умови визначення, що включали: визначення характерних профілів піків настойки нагідок в обраній рухомій фразі за різних довжин хвиль і вибір С3 для перерахунку, оптимізацію етапів підготовки проби випробуваного і С3, етапів дериватизації і детекції; визначення способу розрахунку і розробку формули розрахунку. Так, визначення вмісту суми фрлавоноїдів проводили після розділення речовин в обраній рухомій фразі і дериватизації реагентом алюмінію хлориду за довжини хвилі 408 нм. Для розрахунку обрано метод калібрувального графріку за площею піків. Згідно із розробленою методикою ВETШХ, вміст суми фрлавоноїдів у перерахунку на рутин у зразках настойки

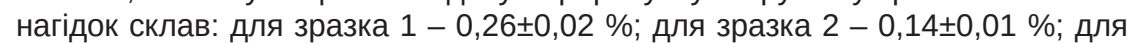
зразка $3-0,26 \pm 0,02 \%$.

Висновки. Розроблену методику можна застосовувати як специфрічний, зручний і економічно вигідний експрес-метод визначення фрлавоноїдів настойки нагідок.
Вступ. Настойка нагідок - лікарський рослинний засіб (ЛР3), який віддавна присутній на ринку України [1]. У настойці нагідок ідентифріковані різні фрлавоноїди: рутин, нарцисин (ізорамнетин-3-О-рутинозид), ізокверцитрин та ін. [2-4]. Зазвичай кількісне визначення настойки нагідок проводять за сумою фрлавоноїдів методом диференційної спектрофотометрії після реакції комплексоутворення з розчинами алю- мінію хлориду в перерахунку на стандартний зразок (С3), шляхом вимірювання абсорбції випробовуваних розчинів за певної довжини хвилі [3-6]. Існують різні варіанти виконання спектрофотометричних визначень суми фрлавоноїдів у настойці нагідок. Так, згідно з вимогами Державної фрармакопеї України (ДФУ), кількісне визначення проводять після кислотного гідролізу, в перерахунку на гіперозид, за довжи-

ISSN 2312-0967. Фармацевтичний часопис. 2021. № 2 
ни хвилі 425 нм, розраховуючи вміст методом питомого показника поглинання (МППП) у перерахунку на гіперозид [5-7]. Інший варіант кількісного визначення суми фрлавоноїдів настойки нагідок - метод диференційної спектрофотометрії з використанням фотометричної реакції з алюмінію хлоридом, але без кислотного гідролізу, шляхом відповідного розведення і у перерахунку на С3 рутину, а розрахунок проводять за методом стандарту (MC) або МППП [3, 6]. Цей варіант є менш специфічним, але враховуючи експресність, малу працемісткість і мінімум стадій підготовки проби, другий варіант має переваги над фрармакопейним способом визначення [6].

Однак спектрофотометрія характеризується низкою недоліків, а саме: вимірювання досліджуваного зразка/зразків і стандартного зразка проводиться не паралельно, а послідовно, що впливає на тривалість процесу, необхідність одночасного задіювання більшої кількості мірного посуду, використання більшої кількості розчинників; метод спектрофротометрії вважається неспецифічним методом аналізу, і при визначенні суми фрлавоноїдів настойки нагідок, згідно із прийнятим принципом стандартизації ЛР3 за сумарним вмістом, відсутня інформація щодо співвідношення компонентів, наприклад, невідомо який саме фрлавоноїд у досліджуваному зразку вносить найбільшу частку в сумарний вміст фрлавоноїдів. Окрім того, в існуючих методиках спектрофотометрії для перерахунку використовують зовнішні маркери (наприклад, гіперозид у методиці ДФУ на настойку нагідок [5]) або специярічні маркери, що містяться у мінорній кількості (наприклад, рутин у настойці нагідок) [4].

Таким чином, розробка альтернативної методики кількісного визначення суми фрлавоноїдів настойки нагідок із використанням специсрічних аналітичних методів є актуальною.

Високоефективна тонкошарова хроматограсрія (BETШX) - $€$ сучасним і специфічним аналітичним методом, що включений до провідних фрармакопей світу для ідентифрікації лікарської рослинної сировини і ЛР3 [8-11]. Разом із цим, сучасне обладнання ВЕТШХ (система для фрото-документування, сканер) і програмне забезпечення дають можливість проводити також і специфічне кількісне визначення речовин, представлених як однією зоною, так і декількома зонами, або навіть усіх - на основі всіх зон хроматографрічного профрілю, за умови їхнього чіткого розділення; документувати і зберігати результати відповідно до вимог GMP. Крім того, у методі ВЕТШХ випробовувані і стандартні зразки визначають одночасно на одній пластинці і за тих самих умов; на одній пластинці може бути проаналізовано до 15 зразків одночасно, що важливо для оптимізації робочого часу в лабораторії та ефективного використання реагентів.

Мета роботи - розробка методики кількісного визначення вмісту суми фрлавоноїдів настойки нагідок методом ВЕТШХ, що характеризується специфічністю, експресністю та економічністю.

Матеріали і методи. Дослідження проведено методом ВЕТШХ в автоматичній системі виробництва CAMAG (Швейцарія) на базі Навчально-наукової тренінгової лабораторії хіміко-технологічних досліджень НФаУ (Харків, Україна). Результати обробляли за допомогою програмного забезпечення visionCats, CAMAG. Як стандартний зразок використовували рутин (USP, Lot H1I146), матеріалом для дослідження були ЛРЗ: «Настойка календули» (ПРаТ «ФІТОФАРМ», сер. 190519, сер. 380819; ПРаТ ФФ «Віола», сер. 120319)

Нижче наведено розроблену методику ВЕТШХ визначення суми фрлавоноїдів, у перерахунку на рутин.

Випробовуваний розчин: поміщають 5 мл попередньо профрільтрованої настойки у мірну колбу на 10 мл, доводять 70 \% етанолом до мітки.

Калібрувальні розчини: готують п'ять 70 \% етанольних розчинів С3 рутину із концентраціями у діапазоні нанесення 0,2-0,8 мкг/зона.

Стаціонарна фраза: HPTLC Si 60 F254 (Merck).

Рухома фраза: етилацетат $P$, мурашина кислота безводна $P$, вода $P$ (8:1:1).

Відстань для хроматографування: 70 мм (від нижнього краю пластинки).

Насичення: 20 хв із фрільтрувальним папером.

Відносна вологість: $33 \%$, насичений розчин $\mathrm{MgCl}_{2}$. Температура: $22 \pm 5^{\circ} \mathrm{C}$.

Дериватизація: 5 \% розчин алюмінію хлориду в 70 \% етанолі. Занурення: час - 0, швидкість - 5 .

Детектування: 366 нм - візуалайзер, 408 нм (максимум поглинання в дифреренційному спектрі рутину) в режимі поглинання - денситометрично із застосуванням ВЕТШХ-сканера, реєстрація спектра в діапа3оні 200-500 нм.

Реєстрація даних і обробка результатів: ПЗ CAMAG visionCATs 2.5.

Сума фрлавоноїдів, у перерахунку на рутин, у настойці нагідок, у відсотках, розраховується за фрормулою:

$$
x, \%=\frac{\left(S_{s u b}-b\right) \times K_{d i l}}{a \times 10 \times V_{a p p l}},
$$

де $\mathrm{S}_{\text {sub }}$ - це сумарне значення площ піків зон фрлавоноїдів у хроматографрічному профрілі настойки нагідок після дериватизації і після віднімання базової лінії і суми площ піків до дериватизації;

a i b - коефріцієнти рівняння регресії;

$\mathrm{K}_{\text {dil }}$ - кратність розведення ЛР3;

$\mathrm{V}_{\text {аррі }}$ - об'єм нанесення настойки, мкл.

Результати й обговорення. Розробка методики кількісного визначення суми фрлавоноїдів настойки нагідок була проведена в уніфікованій рухомій фразі, що застосовується для ідентифрікації фрлавоноїдів і фенілпропаноїдів квіток нагідок / настойки нагідок у відповідних монографріях ДФУ і Європейської фрармакопеї $[2,5,8]$.

ISSN 2312-0967. Pharmaceutical review. 2021. № 2 


\section{Analysis of drugs}

Як СЗ для розрахунку сумарного вмісту фрлавоноїдів у настойці нагідок ми обрали рутин. Рутин є широко розповсюдженим і комерційно доступним фрлавоноїдом і міститься у настойці нагідок. Рутин не $є$ головним фрлавоноїдом настойки нагідок, однак має близькі спектральні характеристики до домінуючої речовини нарцисину [4], що обґрунтовує його застосування для перерахунку кількісного вмісту суми фолавоноїдів. На рисунку 1 наведено хроматограму С3 рутину і зразків настойок нагідок після дериватизації.

Під час розробки методики був проведений вибір реагенту для дериватизації і довжини хвилі для визначення суми фрлавоноїдів настойки нагідок на плас- тинці (рис. 2). Для дериватизації порівнювали два реагенти для виявлення фрлавоноїдів - аміноетиловий етер дифенілборної кислоти і алюмінію хлорид. Шляхом порівняння хроматограм, профрілів піків хроматограми і денситограми за різних довжин хвиль (рис. 2) та за результатами оцінки спектральних характеристик зон рутину треків випробовуваних розчинів і розчинів СЗ рутину до і після хімічної дериватизації (рис. 3,4$)$ як більш специсрічний реагент для кількісного визначення суми фрлавоноїдів ми обрали алюмінію хлорид.

За даними рисунка 1 значення $R_{f}$ рутину досліджуваних зразків настойки нагідок (треки 6-8) і С3 рутину (треки 1-5) збігаються. Збігаються положення мак-

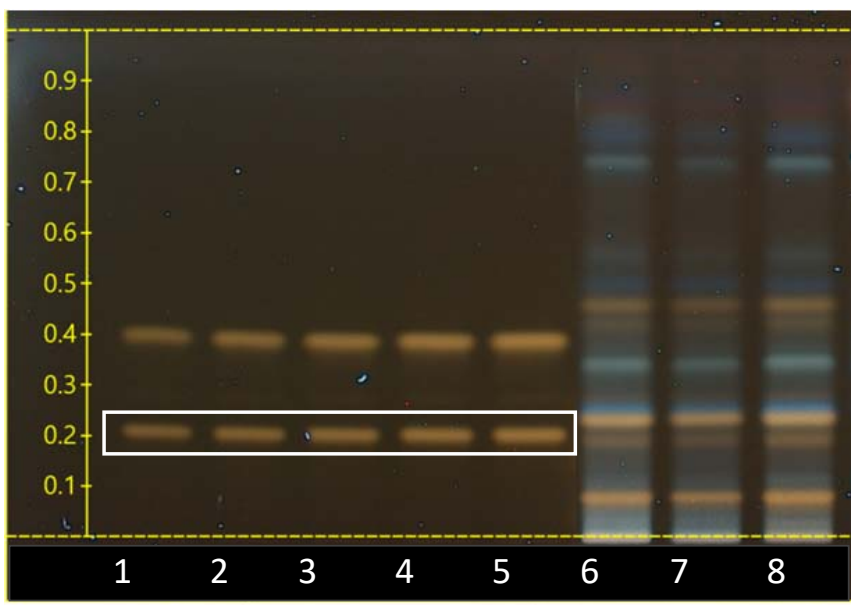

Рис. 1. Хроматограма, отримана для стандартних розчинів рутину $\left(R_{f} \approx 0,2\right)$ і гіперозиду $\left(R_{f} \approx 0,4\right)$ (треки 1-5) і випробовуваних розчинів настойок нагідок (треки 6-8), після дериватизації розчином алюмінію хлоридом $\left(\lambda_{\text {дет }}=366 \mathrm{Hм}\right)$.

A ВETШХ хроматограма (зображення)

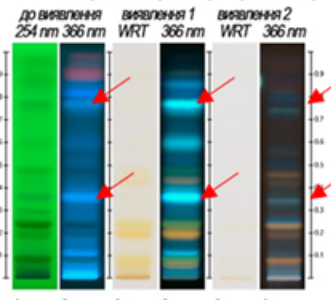

Профіль піків із зображення (PPI)

$254 \mathrm{~mm} 306 \mathrm{~mm}$ WRT $306 \mathrm{~mm}$ WRT $360 \mathrm{~mm}$
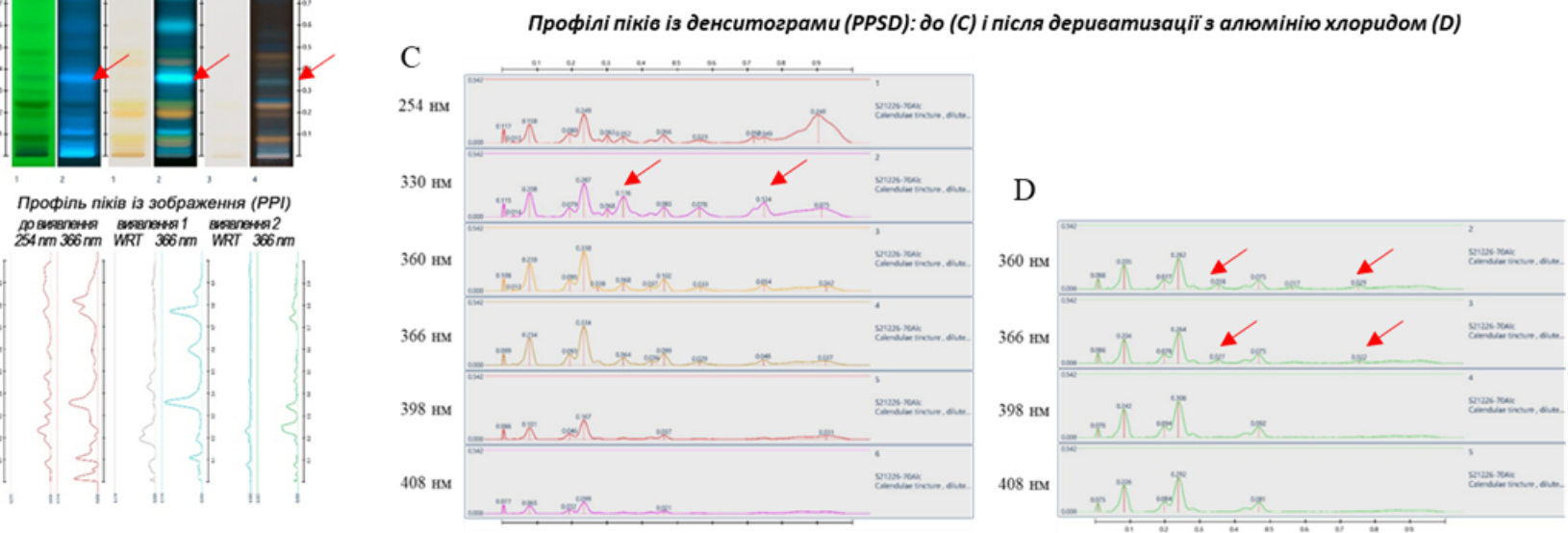

Рис. 2. Вибір реагенту і довжини хвилі для визначення суми фрлавоноїдів настойки нагідок. ВЕТШХ

хроматограми (A) і профрілі піків хроматограм (B) до і після дериватизації (виявлення 1 - реагент аміноетилового етеру дисенілборної кислоти, виявлення 2 - реагент алюмінію хлориду); просрілі піків денситограми до (C) і після (D) дериватизації з реагентом алюмінію хлориду.

ISSN 2312-0967. Фармацевтичний часопис. 2021. № 2 


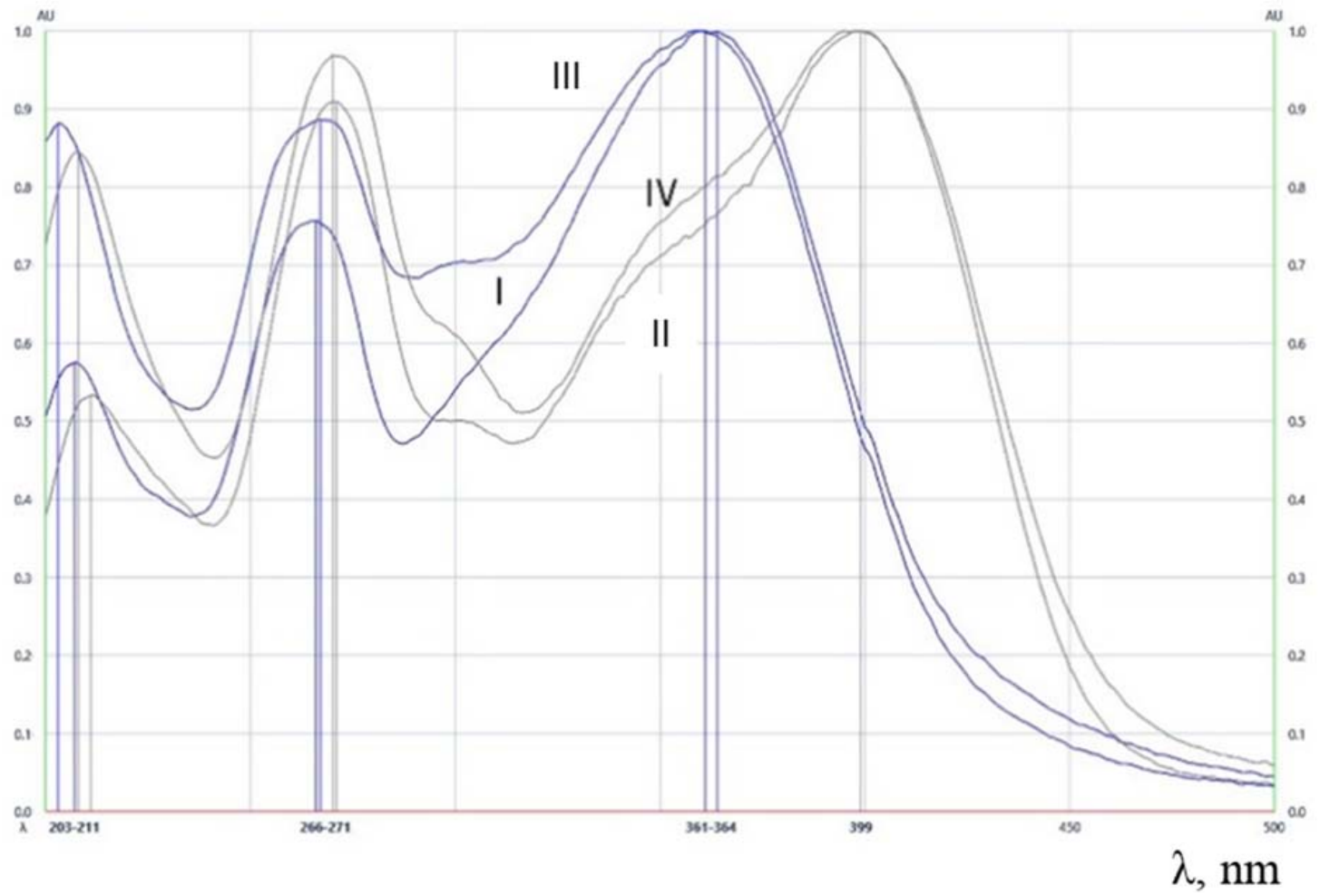

Рис. 3. Електронні спектри поглинання зон рутину: С3 рутину до дериватизації (I) і після дериватизації (II); настойки нагідок до дериватизації (III) і після дериватизації (IV).

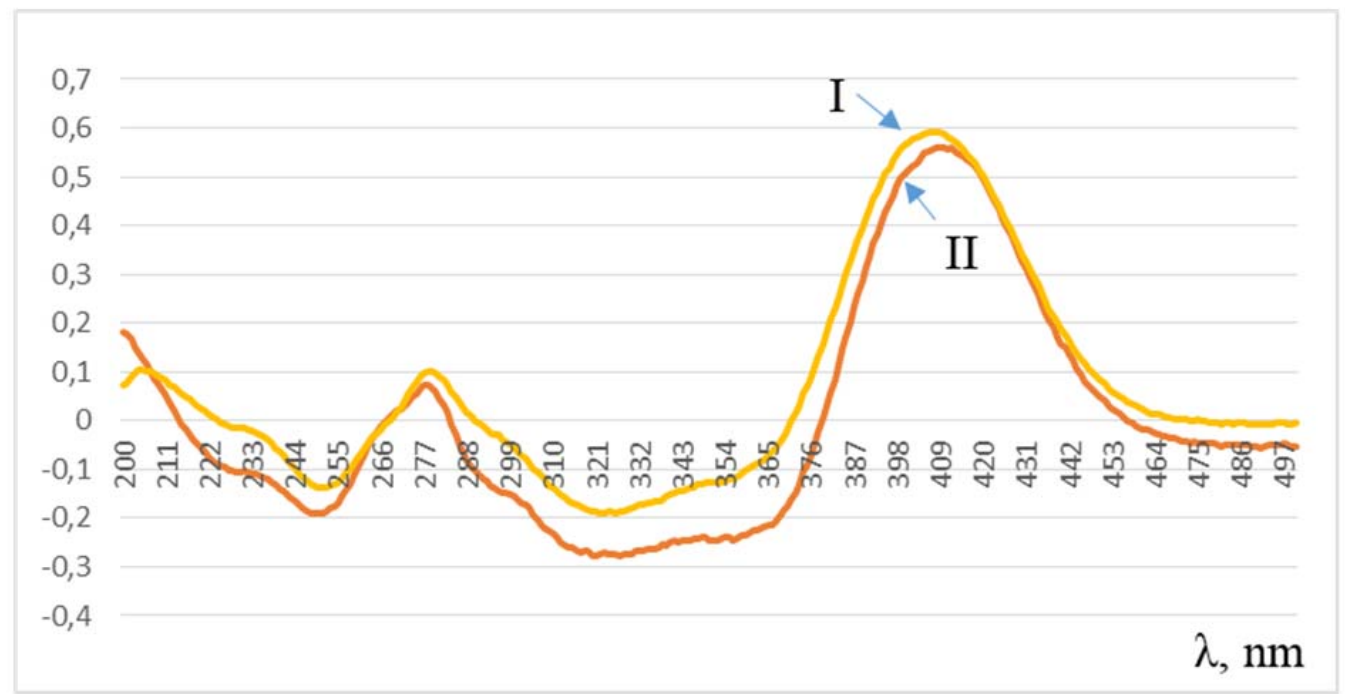

Рис. 4. Диференційні електронні спектри поглинання зон рутину, отримані для: 1 - настойки нагідок (довжина хвилі максимуму абсорбції 405-408 нм); 2 - С3 рутину (довжина хвилі максимуму абсорбції - 408 нм); після реакції комплексоутворення з 5 \% розчином алюмінію хлориду у 70 \% етанолі. 


\section{Analysis of drugs}

симумів абсорбції електронних спектрів зон рутину

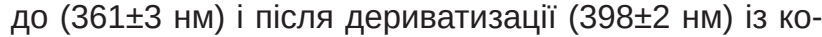
реляцією спектрів $\geq 0,96$ і $\geq 0,95$ відповідно (рис. 3); і положення максимумів абсорбції дифреренційних спектрів зон рутину (408ะ3 нм) випробовуваного розчину настойки нагідок і розчину стандартного зразка (рис. 4). При цьому зони, які відповідають гідроксикоричним кислотам (фенілпропаноїди) та ідентифікуються одночасно із флавоноїдами за довжини хвилі 366 нм (рис. 2, червоні стрілки), не абсорбують за довжини хвилі 408 нм, що дає можливість проводити специфрічне визначення суми фрлавоноїдів за цієї довжини хвилі. Профріль піків зон фрлавоноїдів для треку випробовуваного розчину настойки нагідок після дериватизації при 408 нм наведено на рис. 5. Перерахунок проводили на С3 рутину, нанесений паралель- но із випробуваними розчинами на ту саму пластинку, і для якого спостерігалася лінійність у діапазоні концентрацій 0,2-0,8 мкг/зону. Розрахунок суми фрлавоноїдів, що вступили в реакцію з алюмінію хлоридом, проводили за різницею сумарного значення площ піків зон фрлавоноїдів після дериватизації і до дериватизації при 408 нм. Це дало можливість нівелювати вплив речовин, що поглинають при 408 нм до дериватизації (див. рис. 2).

Кількісний вміст фрлавоноїдів було розраховано різними способами - за розробленою методикою ВЕТШХ за площею (A) і висотою піків (H) як методом калібрувальної кривої (МКК), так і методом стандарту (МС) і визначено спектрофотометрично згідно з методикою [3] після комплексотворення з алюмінію хлоридом, застосовуючи різні способи: МС, МКК, МППП (табл.).

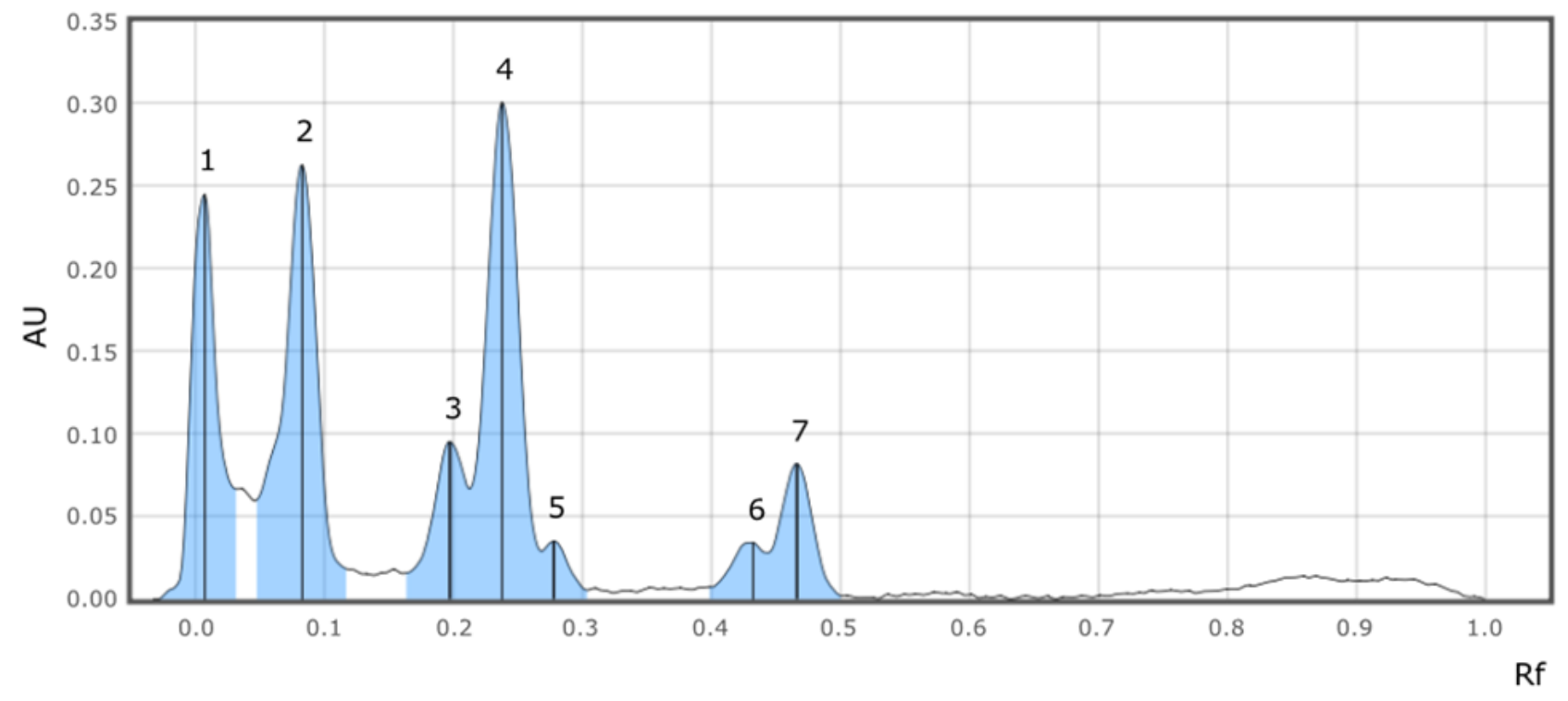

Рис. 5. Профріль піків зон фрлавоноїдів для трека випробовуваного розчину настойки нагідок після дериватизації $\left(\lambda_{\text {дет }}=408 \mathrm{HM}\right)$

\section{Таблиця}

Порівняння результатів кількісного визначення суми фрлавоноїдів настойок нагідок, у перерахунку на рутин, за методом високоефективної тонкошарової хроматографрії і спектрофотометрії при детектуванні за довжини хвилі $408 \mathrm{HM}$

\begin{tabular}{|c|c|c|c|c|c|c|c|}
\hline \multirow{3}{*}{ Спосіб розрахунку } & \multicolumn{4}{|c|}{ Метод ВЕТШХ } & \multicolumn{3}{|c|}{ Метод спектрофотометрії } \\
\hline & \multicolumn{2}{|c|}{ MC } & \multicolumn{2}{|c|}{ МКК } & \multirow{4}{*}{$\mathrm{MC}$} & \multirow[b]{3}{*}{$\begin{array}{l}y=0,0808 x+ \\
0,1176\end{array}$} & \multirow{4}{*}{ МППП } \\
\hline & \multirow{3}{*}{$\mathrm{H}$} & \multirow{3}{*}{ A } & $\mathrm{H}$ & $A$ & & & \\
\hline Рівняння лінійності & & & $\begin{array}{l}y=0,1795 x+ \\
0,041\end{array}$ & $\begin{array}{l}y=0,0057 x+ \\
0,0005\end{array}$ & & & \\
\hline Коесріцієнт кореляції & & & $R^{2}=0,9946$ & $R^{2}=0,9995$ & & $R^{2}=0,9534$ & \\
\hline Зразок & \multicolumn{7}{|c|}{ Вміст, \% } \\
\hline 1 & 0,18 & 0,22 & 0,25 & 0,26 & 0,16 & 0,15 & 0,15 \\
\hline 2 & 0,12 & 0,12 & 0,16 & 0,14 & 0,09 & 0,08 & 0,08 \\
\hline 3 & 0,19 & 0,23 & 0,27 & 0,26 & 0,18 & 0,17 & 0,17 \\
\hline
\end{tabular}

ISSN 2312-0967. Фармацевтичний часопис. 2021. № 2 
За даними таблиці, вміст суми фрлавоноїдів в аналізованих зразках настойки нагідок, отриманий методом ВЕТШХ, вищий від вмісту, отриманого методом спектрофротометрії. Це може зумовлюватись особливостями вимірювання абсорбції зразків у розчинах і нанесених на шар силікагелю, відмінностями $\mathrm{pH}$ та ін. При оцінюванні способу розрахунку вмісту суми фрлавоноїдів методом ВЕТШХ як більш прецизійний і правильний слід рекомендувати МКК [12], а кращу лінійність і вищий коефіцієнт кореляції було отримано при розрахунку за площею піків (див. табл.). Згідно з обраним способом розрахунку, вміст суми орлавоноїдів, у перерахунку на рутин, у зразках настойки нагідок склав для зразків: 1 - 0,26士0,02 \%; 2 $0,14 \pm 0,01 \% ; 3-0,26 \pm 0,02 \%$.
Висновки. Розроблено методику кількісного вмісту суми орлавоноїдів у настойці нагідок за методом BETШХ. Специфічність методики досягається шляхом кількісного визначення суми окремих речовин після їхнього розділення в підхожій рухомій фразі і реакції комплексотворення фрлавоноїдів 3 алюмінію хлориду за довжини хвилі 408 нм. Встановлений кількісний вміст суми фрлавоноїдів корелює з результатами, отриманими методом спектрофротометрії.

Розроблена методика може застосовуватися як простий, специфічний, зручний і економічно вигідний експрес-метод визначення фрлавоноїдів настойки нагідок.

Конфлікт інтересів: відсутній.

Conflicts of interests: authors have no conflicts of interests to declare.

\title{
DETERMINATION OF TOTAL FLAVONOIDS CONTENT IN CALENDULA TICNCTURE BY HIGH- PERFORMANCE THIN-LAYER CHROMATOGRAPHY
}

\author{
K. O. Khokhlova, L. I. Vyshnevska, O. A. Zdoryk \\ National University of Pharmacy, Kharkiv \\ Kateryna_khokhlova@ukr.net
}

The aim of the work. To develop a method for determination of the total flavonoids content (TFC) of Calendula tincture by high-performance thin-layer chromatography (HPTLC) that is specific, fast and economic.

Materials and Methods. The investigation was carried out by HPTLC technique in automated system of CAMAG (Switzerland), on the base of Scientific-Research Training Laboratory of Chemical and Technological Research of the National University of Pharmacy (Kharkiv, Ukraine). The results were evaluated using visionCats software, CAMAG. As a reference standard rutin was used, as objects of study three samples of Calendula tincture of domestic manufactures were used.

Results and Discussion. During development of TFC method the optimal conditions of analysis were chosen, including: determination of characteristic peak profiles of Calendula tincture in the selected mobile phase at different wavelengths; the selection of reference standard for expression, optimization of steps of sample preparation for work and reference solutions, derivatization and detection; determination of calculation's method and calculation formula. Thus, the determination of TFC was carried out after compounds separation in the selected mobile phase and after derivatization with aluminium chloride reagent at a wavelength of $408 \mathrm{~nm}$. For the calculation, the calibration method - plot by peak area was chosen. According to the developed HPTLC methods, the TFC, expressed as rutin, in samples of Calendula tincture was: for sample $1-$ $(0.26 \pm 0.02) \%$; for sample $2-(0.14 \pm 0.01) \%$; for sample $3-(0.26 \pm 0.02) \%$.

Conclusions. The developed method can be used as a specific, convenient and economical express method for determination of TFC in Calendula tincture.

Key words: Calendula tincture; high performance thin-layer chromatography; total flavonoids content; rutin; quantitative determination.

\section{ОПРЕДЕЛЕНИЕ КОЛИЧЕСТВЕННОГО СОДЕРЖАНИЯ СУММЫ ФЛАВОНОИДОВ В НАСТОЙКЕ КАЛЕНДУЛЫ МЕТОДОМ ВЫСОКОЭФФЕКТИВНОЙ ТОНКОСЛОЙНОЙ ХРОМАТОГРАФИИ}

\section{Е. А. Хохлова, Л. И. Вишневская, А. А. Здорик}

Национальный фрармацевтический университет, Харьков

Kateryna_khokhlova@ukr.net

Цель работы. Разработка методики определения количественного содержания суммы фрлавоноидов настойки календулы методом высокоэффективной тонкослойной хроматографии (ВЭТСХ), которая характеризуется специфичностью, экспрессностью и экономичностью.

ISSN 2312-0967. Pharmaceutical review. 2021. № 2 
Аналіз лікарських засобів

Analysis of drugs

Материалы и методы. Исследование было проведено методом ВЭТСХ в автоматической системе производства CAMAG (Швейцария), на базе учебно-научной тренинговой лаборатории химико-технологических исследований НФаУ (Харьков, Украина). Результаты обрабатывали с помощью программного обеспечения visionCats, CAMAG. В качестве стандартного образца (СО) использовали рутин, как объекты исследования использовали три образца настойки календулы отечественных производителей.

Результаты и обсуждения. При разработке методики были выбраны оптимальные условия определения, которые включали: определение характерных профилей пиков настойки календулы в избранной подвижной фразе при различных длинах волн и выбор СО для перерасчета, оптимизацию этапов подготовки пробы испытуемого и СО, этапов дериватизации и детекции; определение способа расчета и разработку фрормулы расчета. Так, определение содержания суммы фрлавоноидов проводилось после разделения веществ в избранной подвижной фразе и дериватизации реагентом алюминия хлорида при длине волны 408 нм. Для расчета был выбран метод калибровочного графика по площади пиков. Согласно разработанной методики ВЭТСХ, содержание суммы фрлавоноидов в пересчете на рутин в образцах настойки календулы составило: для образца $1-0,26 \pm 0,02$ \%; для образца $2-0,14 \pm 0,01 \%$; для образца $3-0,26 \pm 0,02 \%$.

Выводы. Разработанная методика может использоваться как специфический, удобный и экономически выгодный экспресс-метод определения фрлавоноидов настойки календулы.

Ключевые слова: настойка календулы; высокоэффективная тонкослойная хроматография; сумма фрлавоноидов; рутин; количественное определение.

\section{Список бібліографрічних посилань}

1. Державний реєстр лікарських засобів України. URL: http://www.drlz.com.ua/MOZ Ukrainy

2. Хохлова К. О. Розроблення уніфрікованих ВЕТШХ методик для визначення полісренольних сполук у настойках / К. О. Хохлова. Фармац. Журнал. 2020. № 5. С. 68-81.

3. Марахова А. И. Унисрикация фризико-химических методов анализа лекарственного растительного сырья и комплексных препаратов на растительной основе : дисс. д. фрарм. наук : 14.04.02. Москва, 2016. - 313 .

4. Substantiation of new approaches to standardization of herbal materials and pharmaceuticals of Calendula officinalis L. A. V. Kurkina, P. V. Afanasyeva, V.A. Kurkin, et al. Sovrem. Probl. Nauk. i Obraz. 2015. № 5.

5. Державна фрармакопея України 2.0. В 3 т. Харків : ДП «Український науковий фрармакопейний центр якості лікарських засобів», 2015. Т. 3. 732 с.

6. Чубка М. Б., Вронська Л. В., Котляренко Л. Т. Порівняння можливостей застосування різних спектрофотометричних методик для визначення фрлавоної- дів. Фармацевтичний часопис. 2010. № 3. С. 56-61.

7. Котова Е. Е., Котов А. Г. Систематизація фрармакопейних вимог до методів контролю якості лікарської рослинної сировини. Унісріковані спектрофотометричні методики. Фармаком. 2014. № 4. С. 22-34.

8. European Pharmacopoeia 8.0. - Strasbourg: EDQM, 2014. - 3655 p.9. USP Dietary Supplements Compendium [Internet]. 2019 [cited 2019 Oct 1]. Available from: https://www.usp.org/products/dietarysupplements-compendium

10. Державна орармакопея України. 2.2. Харків : ДП «Український науковий фрармакопейний центр якості лікарських засобів», 2018. С. 336.

11. High performance thin-layer chromatography (HPTLC) in the quality control of herbal products. S. Canigueral, D. Frommenwiler, E. Reich, et al. Recent Adv. Pharm. Sci VIII. 2018. P. 119-136.

12. Spangenberg B., Poole C. F., Weins C. Quantitative Thin-Layer Chromatography. A Practical Survey. NewYork: Springer. 2011. 388 p.

\section{References}

1. State Register of Drugs of Ukraine [Internet]. [cited 2019 Jul 9]. Available from: http://www.drlz.com.ua/ MOZ Ukrainy

2. Khokhlova KO. [Development of harmonized HPTLC methods for determination of polyphenolic compounds of tinctures]. Farm Zh. 2020;75(5): 68-81. DOI: 10.32352/0367-3057.5.20.08

3. Marakhova Al. [Unification of physical and chemical methods of drug raw material analysis and complex remedies plant basis]. Doctor's thesis. Moscow; 2016. Russin.

4. Kurkina AV, Afanasyeva PV, Kurkin VA, Platonov IA, Pavlova LV. Substantiation of new approaches to

standardization of herbal materials and pharmaceuticals of Calendula officinalis L. Sovrem Probl Nauk i Obraz. 2015;(5)

5. State Pharmacopoeia of Ukraine 2.0. In 3 volumes. [Державна фрармакопея України 2.0. В 3 т.] DP «Ukrainskyi naukovyi farmakopeinyi tsentr yakosti likarskykh zasobiv»; 2015. Ukrainian.

6. Chubka MB, Vronska LV, Kotlyarenko LT. [Comparison of different spectrophotometric techniques possibilities use for flavonoids definition]. Farm chasop. 2010;(3): 56-61. Ukrainian.

7. Kotova EE, KotovAG. [Systematization pharmacopoeial requirements for methods of quality control of

ISSN 2312-0967. Фармацевтичний часопис. 2021. № 2 
herbal drugs. Unified spectrophotometric methods. Farmakom. 2014;(4): 22-34. Ukrainian.

8. European Pharmacopoeia. European Pharmacopoeia. In 2014. Available from: http://online6.edqm.eu/ep802/

9. USP Dietary Supplements Compendium [Internet]. 2019 [cited 2019 Oct 1]. Available from: https://www. usp.org/products/dietary-supplements-compendium

10. State Pharmacopoeia of Ukraine 2.2. [Державна фрармакопея України 2.2] Kharkiv: DP «Ukrainskyi naukovyi farmakopeinyi tsentr yakosti likarskykh zasobiv»; 2018. Ukrainian.

11. Canigueral S, Frommenwiler D, Reich E, Roser V. High performance thin-layer chromatography (HPTLC) in the quality control of herbal products. Recent Adv Pharm Sci VIII. 2018; 119-36.

12. Spangenberg B, Poole CF, Weins C. Quantitative thinlayer chromatography. A practical survey. New-York: Springer; 2011.

\section{Відомості про авторів}

Хохлова К. О. - канд. фрармац. наук, доцент кафедри аптечної технології ліків, Національний фрармацевтичний університет МО3 України, Харків, Україна. Email: kateryna_khokhlova@ukr.net. ORCID: 0000-0002-7151-6763.

Вишневська Л. І. - д. фрармац. наук, професор, завідувачка кафедри аптечної технології ліків, Національний фрармацевтичний університет МО3 України, Харків, Україна. E-mail: atl@nuph.edu.ua. ORCID: 0000-0002-6887-3591.

Здорик О. А. - д. фрармац. наук, професор, доцент кафедри якості, стандартизації та сертифікації ліків, Національний фрармацевтичний університет МО3 України, Харків, Україна. Email: oleksandr_zdoryk@ukr.net. ORCID: 00000002-2721-0281.

\section{Information about the authors}

Khokhlova K. O. - PhD (Pharmacy), Associate Professor of the Technology Drugs Department, National University of Pharmacy of the Ministry of Health of Ukraine, Kharkiv, Ukraine. Email: kateryna_khokhlova@ukr.net. ORCID: 0000-00027151-6763.

Vyshnevska L. I. - DSc (Pharmacy), Professor, Head of the Technology of Drugs Department, National University of Pharmacy of the Ministry of Health of Ukraine, Kharkiv, Ukraine. Email: atl@nuph.edu.ua. ORCID: 0000-0002-6887-3591 Zdoryk O. A. - DSc (Pharmacy), Professor of the Quality, Control and Standardization Department, National University of Pharmacy of the Ministry of Health of Ukraine, Kharkiv, Ukraine. Email: oleksandr_zdoryk@ukr.net. ORCID: 0000-00022721-0281 